\title{
Exercise: Preventive and Therapeutic Benefits in Cancer
}

\author{
Shashi K. Agarwal
}

Center for Contemporary and Complementary Cardiology, 2227 US Highway 1, Suite 309, North Brunswick, NJ 08902, USA

\begin{abstract}
Cancer is soon expected to overtake cardiovascular diseases as the leading cause of death in the world. As newer and often more expensive cancer treatments become available, several complementary modalities are gaining clinical importance. Exercise is one such modality. Increasing scientific data suggests that exercise, besides helping prevent several cancers, can also help improve outcomes across a range of cancer diagnoses. The mechanisms behind this protection and therapeutic effects are numerous and include changes in body composition, insulin sensitivity, oxidative stress, sex hormone levels, systemic inflammation, immune cell function, and DNA integrity. Exercise is easy to do, is inexpensive, and can be modified to the condition of the patient. This review summarizes the various benefits of structured activity in most major cancers affecting humans.
\end{abstract}

Keywords: Cancer, exercise, physical activity, sedentary lifestyle, breast cancer, lung cancer. colorectal cancer, prostate cancer, metastasis.

\section{INTRODUCTION}

There were nearly 10 million cancer-related deaths in the world, in 2020 [1]. Cancer is now the second leading cause of death globally but is soon expected to become the leading cause [2]. In China, the world's most populous country, cancer is now the leading cause of death [3]. Africa reported 1,109,209 new cases of cancer in 2020 [4] while Asia had 9,503,710 new cancer cases in 2020 [5]. Europe reported $4,398,443$ new cancer cases [6], while the National Cancer Institute estimates that there were 1,806,590 new cases of cancer in the USA in 2020 [7]. According to the World Health Organization (WHO) [8], the most common cancer cases in 2020 were: breast $(2.26$ million), lung (2.21 million), colon and rectum (1.93 million), prostate (1.41 million), skin (non-melanoma) (1.20 million), and stomach (1.09 million) cancer. The most common causes of cancer deaths in 2020 were related to lung (1.80 million), colorectal (935 000), liver (830 000), stomach (769 000), and breast (685 000) cancer.

Most cancers arise from complex pathogenesis involving genetic, environmental, and lifestyle factors [10]. Anand et al. reported that up to almost $95 \%$ of cancer events are attributable to lifestyle factors such as physical inactivity, cigarette smoking, poor diet, alcohol, and obesity [11]. The lifestyle factors involved are generally modifiable. Physical activity (PA), including structured exercise, is one such modifiable lifestyle [12]. Physical activity before cancer treatment

*Address correspondence to this author at the Center for Contemporary and Complementary Cardiology, 2227 US Highway 1, Suite 309, North Brunswick, NJ 08902, USA; Tel: 1-732-895-3200; E-mail: usacardiologist@gmail.com prognosticates better outcomes. It helps mitigate common cancer-related health problems, including anxiety, depressive symptoms, fatigue, and diminished physical functioning [15]. During treatment, it helps improve treatment effectiveness and diminishes treatment-related side effects. Exercise also helps prevent cancer recurrence, both local and distant. The overall quality of life (QOL) improves in these patients, and cancer-related mortality is reduced.

\section{DISCUSSION}

Physical activity is defined as any bodily movement produced by skeletal muscles that result in energy expenditure [13], while exercise is a subcategory of physical activity, and is planned, repetitive, and purposive [14]. Physical activities are commonly classified according to the metabolic equivalent (MET) expended. One MET equals an energy expenditure of $1 \mathrm{kcal} / \mathrm{kg} / \mathrm{hour}$ or an oxygen uptake of $3.5 \mathrm{ml} / \mathrm{kg} / \mathrm{min}$. Light-intensity activities expend less than 3 METs, moderate-intensity activities expend 3 to 6 METs, and vigorous activities expend 6 or more METs. Exercises may be aerobic or resistance, but also include stretching, balance and gait workouts, and nontraditional activities such as tai chi and yoga. Activities such as walking, cycling, jogging, and swimming are primarily aerobic exercises. They increase mitochondrial density, insulin sensitivity, oxidative enzymes, blood vessel compliance and reactivity, lung function, immune function, and cardiovascular function [15]. Resistance exercises include workouts with free weights, weight machines, bodyweight, or elastic resistance bands. They result in improvements in muscle mass, body composition, strength, physical function, bone mineral density, insulin sensitivity, blood 
pressure, lipid profiles, and cardiovascular health [16]. Stretching increases the range of motion around joints and enhances flexibility. Balance training can reduce falls risk by improving balance and gait. Activities like tai chi and yoga combine flexibility, balance, and resistance exercises. Besides the physical benefits, all exercises also improve mental and emotional health [17].

Physical activity plays a significant preventive and therapeutic role in cancer [18-21]. In Germany, it is estimated that low physical activity accounts for $6 \%$ of all cancers [22], while in the US, it is estimated to account for $2.9 \%$ of all cancers [23]. Physical activity and structured exercise have significant benefits in cancer prevention [24]. In a large study (1.44 million participants and 186,972 cancers), significant cancer prevention in 13 common cancers was noted with exercise when high vs low levels of leisure-time physical activity was compared [24]. These included cancers of the esophageal (adenocarcinoma) (Hazard Ratio or $H R=0.58)$, liver ( $H R=0.73)$, lung $(H R=0.74)$, kidney $(H R=0.77)$, gastric cardia $(H R=0.78)$, endometrium $(H R=0.79)$, colon $(H R=0.84)$, head and neck $(H R=0.85)$, rectum $(H R=0.87)$, bladder $(H R=$ $0.87)$, and breast $(H R=0.90)$. There was also a reduction noted in myeloid leukemia $(H R=0.80)$, myeloma $(\mathrm{HR}=0.83)$ [24]. Leisure-time physical activity, however, increased the risks of malignant melanoma $(H R=1.27)$ and prostate cancer $(H R=1.05)$ in this study [24]. A more recent umbrella review, which included 19 reviews, 26 meta-analyses, and 541 original studies, also concluded that regular physical activity is beneficial in preventing several cancers, including those of the colon, breast, endometrium, lung, esophagus, pancreas, and meninges [25]. Prevention benefits even occur with minimal amounts of exercise, and there appears to be a dose-dependent relationship [26]. Further, long-term or lifetime physical activity also influences cancer prevention, as the process of normal cells becoming invasive tumors usually takes many years [27]. Exercise therapy before the initiation of chemotherapy, or before surgical intervention, is also associated with improvements in tolerance to treatment [28].

Exercise during treatment may increases treatment efficacy, be it chemotherapy, immunotherapy, or radiation therapy, by decreasing tumor hypoxia [29-31]. It also helps reduce treatment-related side effects. These include anxiety, depression, reduced bone density, fatigue, lymphedema, poor functional status, disturbed sleep, and poor QOL. Exercise may also help ameliorate certain other problems related to cancer and its treatment. These include cardiotoxicity, chemotherapy-induced peripheral neuropathy, balance impairment, falls, cognitive dysfunction, nausea, and pain. It also helps improve sexual dysfunction often noted in prostate cancer following androgen deprivation therapy (ADT). Exercise may also help retard tumor progression [32]. Animal studies have reported a reduction in tumor mass with high-intensity training. Exercise in humans has also been shown to reduce cell proliferation and increase markers of apoptosis. Higher levels of exercise have been noted to cause a statistically significant reduction in cancer recurrence (local and distant) in patients with three common cancers - those involving the breast, colorectal tissue, and prostate. Cormie et al. in a meta-analysis review calculated that the pooled HRs ranged from 0.79 to 0.76 for this reduction [33]. Distant metastases are responsible for $90 \%$ of all cancer-related deaths [34], and exercise helps prevent metastasis [35]. Exercise increases tumor vasculature, and this appears to retard the spread of tumor cells to distant organs [36]. Animal studies indicate that exercise may prevent brain metastasis in lung cancer and lung metastasis in breast cancer. Precancer exercise and exercise during and after cancer treatment also improves longevity [37]. Higher levels of physical activity appear to be more effective in reducing cancer mortality. Cornie et al. in a meta-analytic review calculated that highly active and exercising cancer patients had a lower relative risk of all-cause mortality (pooled HRs range from 0.75 to 0.52 ) [33]. Another study found a mortality reduction of $48 \%$ in nearly 14,000 cancer survivors, at least three years post-treatment with adherence to both aerobic and resistance physical activity guidelines [38]. Although both aerobic and resistance exercise help individually, data supports the combination of aerobic and resistance exercise has a synergizing anti-cancer effect [39].

Cancer and its treatment, usually cause physical discomfort and mental deterioration, reducing the desire and ability to exercise [40]. However, most studies find exercise safe during and after treatment and have reported negligible adverse effects [41]. Most international institutions recommend that adults engage in moderate-intensity physical activity for at least 30 minutes a day for five days a week, or exercise at a high intensity for at least 20-30 minutes, three or more days a week [42]. Regular exercise is also recommended by various oncology health experts and organizations. A recent set of guidelines from the American College of Sports Medicine International 
Multidisciplinary Roundtable on Physical Activity and Cancer Prevention and Control in 2018 recommend that cancer patients partake in moderate-intensity aerobic training at least three times per week, for at least $30 \mathrm{~min}$ each session, for 8 to 12 week [43]. They also recommend adding resistance training to aerobic training, at least two times per week. The resistance exercises should consist of two sets of 8 to 15 repetitions per set, per exercise. Each repetition should be at least $60 \%$ of the maximum weight the patient can lift or press for a given exercise. Supervised exercise is associated with better compliance [44]. More than $40 \%$ of the patients diagnosed with cancer have comorbid diseases (such as diabetes, obesity, chronic obstructive pulmonary disease, heart failure, and coronary artery disease) [45]. Exercise in cancer patients also helps diminish the harmful impact of these comorbid non-communicable diseases [46].

Physical activity induces a reduction in adipose tissue [47], improves insulin resistance [48], reduces the inflammatory state, and beneficially regulates the immune system [49]. Exercise also helps modulate endogenous sex hormone levels [50], enhances resistance to oxidative stress [51], and helps repair DNA damage [52].

\section{EXERCISE AND LUNG CANCER}

Exercise helps reduce the risk of lung cancer by 20 $30 \%$ in women and $20-50 \%$ in men [53]. Preoperative exercises in lung cancer improve pulmonary function before surgery [54]. These help in reducing the duration of hospital stay and help reduce postoperative complications after lung resection surgery [54]. Postoperatively, these patients report a significant improvement in QOL [55]. Studies in animals suggest that brain metastasis in lung cancer may also be reduced with exercise [56].

\section{EXERCISE AND BREAST CANCER}

Several studies have demonstrated that physical activity results in lowering the breast cancer risk [57]. Women who are the most physically active have a $25 \%$ less chance of getting breast cancer when compared to those that are the least physically active. Even recreational and household activities of moderateintensity and sustained over a lifetime appeared to be cancer preventive. Exercise during the treatment of breast cancer helps mitigate treatment-related side effects such as fatigue, stress, depression, and lymphedema [58]. Exercise helps improve cardiorespiratory fitness, increase muscular strength, and improve the quality of life in these patients [59]. It helps reduce metastasis and improves overall survival.

\section{EXERCISE AND COLORECTAL CANCER}

Exercise also helps prevent colon cancers [60]. A meta-analysis showed that physical activity resulted in a $24 \%$ decrease in colon cancer risk [61], while another study found that exercising 7 hours a week reduced the risk by $40 \%$ [62]. Physical activity, especially in higher volumes, is associated with less fatigue, better bowel function, more salubrious sleep, lesser stress, and improved QOL [63]. However, up to $90 \%$ of colon cancer survivors do not engage in the recommended minimum volume of $150 \mathrm{~min} /$ week of physical activity [64], despite several studies correlating higher volume of exercise (up to $300 \mathrm{~min} /$ week) with improved disease outcomes in these patients [65]. Increased physical activity has also been associated with significant reductions in mortality for survivors of colorectal cancer [66].

\section{EXERCISE AND PROSTATE CANCER}

Several systemic reviews and meta-analyses have suggested that total physical activity, including leisuretime physical activity, leads to a decrease in the risk of developing prostate cancer [67]. In addition, epidemiological studies have shown that exercise, after a prostate cancer diagnosis, results in better outcomes with treatment [68]. Prostate cancer treatment is often associated with fatigue, and diminished quality of life, and exercise helps mitigate these [69]. In patients on ADT, exercise helps control abdominal fat and the BMI [70]. The patients develop better muscle strength and become more exercise tolerant [70]. Sexual function and QOL also improves. In patients with bone metastasis, exercise by improving physical fitness helps decrease the risk of developing pathological fractures, hypercalcemia, bone marrow suppression, and nerve compression or spinal cord compression [71]. Mortality is also reduced by about $38 \%$ between the highest versus lowest levels of physical activity in these patients [72].

\section{EXERCISE AND STOMACH CANCER}

In a 2016 meta-analysis, the risk of gastric cancer was reduced by approximately $19 \%$ for individuals engaging in highest versus lowest levels of activity [73]. More recently, Xie et al. found that when patients with high PA were compared to those with low PA, there was a reduction of $17 \%$ in gastric cancer in the former [74]. Gastric cancer patients also tend to become 
sarcopenic and frail, and a combination of resistance and endurance exercises improves muscle mass and increases strength and function in these patients [75]. Exercise done preoperatively helps improve postoperative outcomes [76]. Exercise also helps combat functional decline that gets aggravated with chemotherapy and chemoradiation in these patients [77].

\section{EXERCISE AND LIVER CANCER}

Physical activity is inversely related to the risk of liver cancer [78]. In a large meta-analysis (8440 liver cancer cases) high vs low physical activity reduced the risk of liver cancer by $25 \%$ [79]. Sedentary behavior modification by increasing walking times and decreasing screen times also appears to reduce the risk of liver cancer [80]. An umbrella review was inconclusive to support a beneficial effect of physical activity for lowering the risk of liver cancer [81]. However, the beneficial effects of exercise on retarding liver cancer were recently documented in mice [82]. Perioperative exercise therapy for patients with hepatocellular carcinoma improves physical fitness and shortens hospital stay and results in an earlier resumption of daily exercise after hepatectomy [83]. Studies have also noted an inverse association between total physical activity and liver cancer mortality [79].

\section{EXERCISE AND ESOPHAGEAL CANCER}

Physical activity decreases esophageal cancer [84]. Poor physical fitness preoperatively results in poor tolerance of peri-operative oncological treatment, with increased toxicity, longer hospital stay, and long-term adverse events [85]. They also demonstrate decreased long-term survival [86]. Better physically fit patients do better [87]. Perioperative exercise to improve physical conditioning reduces adverse outcomes [88]. Postoperative exercises also help improve their QOL [89].

\section{EXERCISE AND THYROID CANCER}

Daily walking reduces the risk of thyroid cancer [90]. Thyroid hormone replacement after thyroidectomy may result in fatigue, anxiety, and poor QOL, which is mitigated by a home-based exercise program [91].

\section{EXERCISE AND URINARY BLADDER CANCER}

Keimling et al. found a reduced risk of bladder cancer among individuals with the highest levels of physical activity (Risk Ratio=0.86) [92]. Another study reported a $47 \%$ decreased risk of bladder cancer death in exercising individuals [93].

\section{EXERCISE AND KIDNEY CANCER}

A meta-analysis, published in 2013, reported that the risk of renal cancer was lower for individuals engaging in the highest versus lowest categories of physical activity level $(R R=0.88)$ [94]. Exercise also helps control or reduce obesity, which independently increases kidney cancer risk and kidney cancer mortality [95]. In multivariate analyses of 222,163 individuals, "any physical activity" was associated with $50 \%$ fewer kidney cancer deaths than that seen in nonexercisers [95]. Exercise improves QOL in kidney cancer patients [96]

\section{EXERCISE AND GYNECOLOGICAL CANCER}

There is substantial scientific evidence that physical activity, amounting to $>30$ min per day, reduces the risk of endometrial cancer [97]. This reduction was estimated to be $25 \%$ with moderate and vigorous recreational exercise [98]. Physical activity in cervical cancer can result in improvements in fatigue and sexual functioning. Cervical cancer patients may also notice an improved quality of life and enhanced survivorship by increasing physical exercise [99].

\section{EXERCISE AND SKIN CANCER}

Physical activity outdoors increases the risk of skin cancer [100] due to excessive exposure to solar radiation [101]. This can be reduced by exercising indoors [102]. Outdoor exercising patients should protect themselves against UV radiation and comply with regular skin examinations to detect early skin cancer, thereby reducing the incidence, morbidity, and mortality of skin cancer [102].

\section{EXERCISE AND OTHER CANCERS}

There is evidence suggesting an association between higher physical activity and decreased risks of hematologic cancers (myeloid neoplasms (myelodysplastic syndromes, acute myeloid leukemia, myeloproliferative neoplasms, chronic lymphocytic leukemia, small lymphocytic lymphoma, and mature B cell lymphomas), head and neck cancers, and pancreatic cancers [103]. The relationship between physical activity and ovarian cancer remains unclear [104].

\section{CONCLUSION}

Physical activity appears to play an important role in cancer. It not only plays an important preventive role, but it also retards the progression of several cancers, reduces recurrence, and increases survival. It helps 
attenuate cancer treatment-related side effects. Besides, it also helps diminish the adverse impact of chronic co-morbid conditions that many of these patients have. Exercise also helps improve the psychological health of these patients. Overall, cancer patients notice an improved health-related quality of life with exercise. Both aerobic and resistance exercises are beneficial. Stretching, flexibility, balance, and nontraditional exercises like yoga and tai chi provide added benefits. Exercise should be of at least moderate intensity. More exercise is better as there appears to be a dose-dependent relationship. Overall, the benefits of exercise in cancer are extremely persuasive. A structured exercise program, ideally supervised, should be an integral component of the "standard of care" in cancer management.

\section{ACKNOWLEDGEMENTS}

None.

\section{FUNDING}

None.

\section{CONFLICT OF INTEREST}

None.

\section{REFERENCES}

[1] Ferlay J, Ervik M, Lam F, Colombet M, Mery L, Piñeros M, et al. Global Cancer Observatory: Cancer Today. Lyon: International Agency for Research on Cancer; 2020. https://gco.iarc.fr/today accessed February 2021.

[2] Dagenais GR, Leong DP, Rangarajan S, et al. Variations in common diseases, hospital admissions, and deaths in middleaged adults in 21 countries from five continents (PURE): a prospective cohort study. Lancet 2020; 395(10226): 785-794. https://doi.org/10.1016/S0140-6736(19)32007-0

[3] Feng RM, Zong YN, Cao SM, et al. Current cancer situation in China: good or bad news from the 2018 Global Cancer Statistics? Cancer Commun 2019; 39: 22. https://doi.org/10.1186/s40880-019-0368-6

[4] https://gco.iarc.fr/today/data/factsheets/populations/935-asia-factsheets.pdf - accessed May 30, 2021.

[5] Sung H, Ferlay J, Siegel RL, Laversanne M, Soerjomataram I, Jemal A, Bray F. Global cancer statistics 2020: GLOBOCAN estimates of incidence and mortality worldwide for 36 cancers in 185 countries. CA Cancer J Clin 2021. https://doi.org/10.3322/caac. 21660

[6] https://www.euro.who.int/en/health-topics/noncommunicablediseases/cancer/data-and-statistics - accessed December 23, 2020.

[7] Noone AM, Howlader N, Krapacho M, et al. SEER cancer statistics review, 1975-2015 Bethesda, MD: National Cancer Institute 2018

[8] https://www.who.int/news-room/fact-sheets/detail/cancer accessed June 1, 2021

[9] Cogliano VJ, Baan R, Straif K, Grosse Y, Lauby-Secretan B, El Ghissassi $\mathrm{F}$, et al. Preventable exposures associated with human cancers. Journal of the National Cancer Institute 2011; 103(24): 1827-39.

https://doi.org/10.1093/jnci/dir483 https://www.cancer.org/cancer/cancer-in-children/risk-factorsand-causes.html - accessed June 10, 2021.

[11] Anand $P$, Kunnumakkara $A B$, Sundaram $C$, Harikumar $K B$ Tharakan ST, Lai OS, et al. Cancer is a preventable disease that requires major lifestyle changes. Pharm Res 2008; (9): 2097-116. https://doi.org/10.1007/s11095-008-9661-9

[12] Garber CE, Blissmer B, Deschenes MR, Franklin BA, Lamonte MJ, Lee IM, Nieman DC, Swain DP; American College of Sports Medicine. American College of Sports Medicine position stand. Quantity and quality of exercise for developing and maintaining cardiorespiratory, musculoskeletal, and neuromotor fitness in apparently healthy adults: guidance for prescribing exercise. Med Sci Sports Exerc 2011; 43(7): 1334-59.

https://doi.org/10.1249/MSS.0b013e318213fefb

[13] Caspersen CJ, Powell KE, Christenson GM. Physical activity, exercise, and physical fitness: definitions and distinctions for health-related research. Public Health Rep 1985; 100: 126.13.

[14] https://healthyliving.azcentral.com/acsm-definition-

cardiovascular-exercise-18723.html - accessed November 18, 2020

[15] Colberg SR, Sigal RJ, Yardley JE, Riddell MC, Dunstan DW, Dempsey PC, Horton ES, Castorino K, Tate DF. Physical Activity/Exercise and Diabetes: A Position Statement of the American Diabetes Association. Diabetes Care 2016; 39(11): 2065-2079.

\section{https://doi.org/10.2337/dc16-1728}

[16] Garber CE, Blissmer B, Deschenes MR, et al. American College of Sports Medicine. American College of Sports Medicine position stand. Quantity and quality of exercise for developing and maintaining cardiorespiratory, musculoskeletal, and neuromotor fitness in apparently healthy adults: guidance for prescribing exercise. Med Sci Sports Exerc 2011; 43: 1334-1359.

https://doi.org/10.1249/MSS.0b013e318213fefb

[17] Mikkelsen K, Stojanovska L, Polenakovic M, Bosevski $M$ Apostolopoulos V. Exercise and mental health. Maturitas 2017 106: 48-56.

\section{https://doi.org/10.1016/j.maturitas.2017.09.003}

[18] Moore SC, Lee IM, Weiderpass E, et al. Association of LeisureTime Physical Activity With Risk of 26 Types of Cancer in 1.44 Million Adults. JAMA Intern Med 2016; 176(6): 816-25. https://doi.org/10.1001/jamainternmed.2016.1548

[19] Chen HHW, Kuo MT. Improving radiotherapy in cancer treatment: Promises and challenges. Oncotarget 2017; 8(37): $62742-62758$.

https://doi.org/10.18632/oncotarget.18409

[20] Mustian KM, Griggs JJ, Morrow GR, et al. Exercise and side effects among 749 patients during and after treatment for cancer: a University of Rochester Cancer Center Community Clinical Oncology Program Study. Support Care Cancer 2006; 14: 732741.

https://doi.org/10.1007/s00520-005-0912-6

[21] Islami F, Goding Sauer A, Miller KD, et al. Proportion and number of cancer cases and deaths attributable to potentially modifiable risk factors in the United States. CA: A Cancer Journal for Clinicians 2018; 68: 31-54 https://doi.org/10.3322/caac.21440

[22] Cormie P, Zopf EM, Zhang X, Schmitz KH. The Impact of Exercise on Cancer Mortality, Recurrence, and TreatmentRelated Adverse Effects. Epidemiol Rev 2017; 39(1): 71-92. https://doi.org/10.1093/epirev/mxx007

[23] Behrens G, Gredner T, Stock C, et al. Cancers Due to Excess Weight, Low Physical Activity, and Unhealthy Diet. Dtsch Arzteb Int 2018; 115(35-36): 578-585. https://doi.org/10.3238/arztebl.2018.0578

[24] Moore SC, Lee IM, Weiderpass E, et al. Association of LeisureTime Physical Activity With Risk of 26 Types of Cancer in 1.44 Million Adults. JAMA Intern Med 2016; 176(6): 816-25. https://doi.org/10.1001/jamainternmed.2016.1548

[25] Rezende LFM, Sá TH, Markozannes G, Rey-López JP, Lee IM, Tsilidis KK, Ioannidis JPA, Eluf-Neto J. Physical activity and cancer: an umbrella review of the literature including 22 major anatomical sites and 770000 cancer cases. Br J Sports Med 2018; 52: 826-833.

https://doi.org/10.1136/bjsports-2017-098391 
[26] McTiernan A, Friedenreich CM, Katzmarzyk PT, Powell KE, Macko R, Buchner D, Pescatello LS, Bloodgood B, Tennant B, Vaux-Bjerke A, George SM, Troiano RP, Piercy KL; Physical Activity in Cancer Prevention and Survival: A Systematic Review. Med Sci Sports Exerc 2019; 51(6): 1252-1261. https://doi.org/10.1249/MSS.0000000000001937

[27] White E, Hunt JR, Casso D. Exposure measurement in cohort studies: the challenges of prospective data collection. Epidemiol Rev 1998; 20(1): 43-56.

https://doi.org/10.1093/oxfordjournals.epirev.a017971

[28] https://www.mdanderson.org/cancerwise/can-exercise-makechemotherapy-more-effective-for-cancer-treatment.h00159301467.html.

[29] Betof AS, Lascola CD, Weitzel D, et al. Modulation of murine breast tumor vascularity, hypoxia and chemotherapeutic response by exercise. J Natl Cancer Inst 2015; 107(5): djv040. https://doi.org/10.1093/inci/djv040

[30] Schadler KL, Thomas NJ, Galie PA, et al. Tumor vessel normalization after aerobic exercise enhances chemotherapeutic efficacy. Oncotarget 2016; 7(40): 65429-65440. https://doi.org/10.18632/oncotarget.11748

[31] Chen HHW, Kuo MT. Improving radiotherapy in cancer treatment: Promises and challenges. Oncotarget 2017; 8(37): 62742-62758 https://doi.org/10.18632/oncotarget.18409

[32] Ashcraft KA, Peace RM, Betof AS, Dewhirst MW, Jones LW. Efficacy and Mechanisms of Aerobic Exercise on Cancer Initiation, Progression, and Metastasis: A Critical Systematic Review of In vivo Preclinical Data. Cancer Res 2016; 76(14): 4032-50. https://doi.org/10.1158/0008-5472.CAN-16-0887

[33] Cormie $P$, Zopf EM, Zhang X, Schmitz KH. The Impact of Exercise on Cancer Mortality, Recurrence, and TreatmentRelated Adverse Effects. Epidemiol Rev 2017; 39(1): 71-92. https://doi.org/10.1093/epirev/mxx007

[34] Spano D, Heck C, De Antonellis P, Christofori G, Zollo M. Molecular networks that regulate cancer metastasis. Semin Cancer Biol 2012; 22(3): 234-49.

https://doi.org/10.1016/i.semcancer.2012.03.006

[35] Ashcraft KA, Peace RM, Betof AS, Dewhirst MW, Jones LW. Efficacy and mechanisms of aerobic exercise on cancer initiation, progression, and metastasis: a critical systematic review of in vivo preclinical data. Cancer Res 2016; 76: 4032-4050. https://doi.org/10.1158/0008-5472.CAN-16-0887

[36] Lambert AW, Pattabiraman DR, Weinberg RA. Emerging biological principles of metastasis. Cell 2017; 168(4): 670-91. https://doi.org/10.1016/i.cell.2016.11.037

[37] Grisham J. What are the benefits of exercise during and after cancer treatment? Memorial Sloan Kettering Cancer Center 2014. www.mskcc.org/blog/what-are-benefits-exercise-duringand-after-treatment. Accessed Jun. 18, 2016.

[38] Tarasenko YN, Linder DF, and Miller EA. Muscle-strengthening and aerobic activities and mortality among 3+ year cancer survivors in the U.S. Cancer Causes Control 2018; 29(4-5): 47584.

\section{https://doi.org/10.1007/s10552-018-1017-0}

[39] Saeidifard F, Medina-Inojosa JR, West CP, Olson TP, Somers VK, Bonikowske AR, Prokop LJ, Vinciguerra M, Lopez-Jimenez $F$. The association of resistance training with mortality: a systematic review and meta-analysis. Eur J Prev Cardiol 2019; 26: 1647-1665. https://doi.org/10.1177/2047487319850718

[40] Coletta AM, Marquez G, Thomas P, Thoman W, Bevers T, Brewster AM, Hawk E, Basen-Engquist K, Gilchrist SC. Clinical factors associated with adherence to aerobic and resistance physical activity guidelines among cancer prevention patients and survivors. PLoS One 2019; 14 https://doi.org/10.1371/journal.pone.0220814

[41] Speck RM, Courneya KS, Masse LC, Duval S, Schmitz KH. An update of controlled physical activity trials in cancer survivors: a systematic review and meta-analysis. J Cancer Surviv Res Pract 2011; 5(1): 112. vol 4, pg 87, 2010.

https://doi.org/10.1007/s11764-010-0137-7
[42] Winzer BM, Whiteman DC, Reeves MM, Paratz JD. Physical activity and cancer prevention: A systematic review of clinical trials. Cancer Causes Control 2011; 22: 811-826.

https://doi.org/10.1007/s10552-011-9761-4

[43] Campbell KL, Winters-Stone KM, Wiskemann J, et al. Exercise Guidelines for Cancer Survivors: Consensus Statement from International Multidisciplinary Roundtable. Med Sci Sports Exerc 2019; 51(11): 2375-2390. https://doi.org/10.1249/MSS.0000000000002116

[44] Segal R, Zwaal C, Green E, et al. Exercise for people with cancer: a systematic review. Curr Oncol 2017; 24(4): e290-e315. https://doi.org/10.3747/co.24.3619

[45] Lobelo F., Rohm Young D., Sallis R. Routine assessment and promotion of physical activity in healthcare settings: a scientific statement from the American Heart Association. Circulation 2018; 137: e495-e522. https://doi.org/10.1161/CIR.0000000000000559

[46] Squires RW, Shultz AM, Herrmann J. Exercise Training and Cardiovascular Health in Cancer Patients. Curr Oncol Rep 2018; 20: 27 . https://doi.org/10.1007/s11912-018-0681-2

[47] Kyrgiou M, Kalliala I, Markozannes G, et al. Adiposity and cancer at major anatomical sites: umbrella review of the literature. BMJ 2017; 356: j477. https://doi.org/10.1136/bmj.j477

[48] Hvid T.Winding K. Rinnov A.et al. Endurance training improves insulin sensitivity and body composition in prostate cancer patients treated with androgen deprivation therapy.Endocr. Relat. Cancer 2013; 20: 621-632.

https://doi.org/10.1530/ERC-12-0393

[49] Hojman P. Exercise protects from cancer through regulation of immune function and inflammation. Biochem Soc Trans 2017; 45(4): 905-11.

https://doi.org/10.1042/BST20160466

[50] de Roon M, May AM, McTiernan A, Scholten RJPM, Peeters PHM, Friedenreich CM, Monninkhof EM. Effect of exercise and/or reduced calorie dietary interventions on breast cancer-related endogenous sex hormones in healthy postmenopausal women. Breast Cancer Res 2018; 20(1): 81. https://doi.org/10.1186/s13058-018-1009-8

[51] Alves CRR, Neves WD, de Almeida NR, et al. Exercise training reverses cancer-induced oxidative stress and decrease in muscle COPS2/TRIP15/ALIEN. Mol Metab 2020; 39: 101012. https://doi.org/10.1016/..molmet.2020.101012

[52] Matos B, Patrício D, Henriques MC, et al. Chronic exercise training attenuates prostate cancer-induced molecular remodelling in the testis. Cell Oncol (Dordr) 2021; 44(2): 311-327. https://doi.org/10.1007/s13402-020-00567-9

[53] Emaus A, Thune I. Physical activity and lung cancer prevention. Recent Results Cancer Res 2011; 186: 101-33. https://doi.org/10.1007/978-3-642-04231-7 5

[54] Sebio Garcia R, Yáñez Brage MI, Giménez Moolhuyzen E, Granger CL, Denehy L. Functional and postoperative outcomes after preoperative exercise training in patients with lung cancer: a systematic review and meta-analysis. Interact Cardiovasc Thorac Surg 2016; 23(3): 486-97.

https://doi.org/10.1093/icvts/ivw152

[55] Jones LW, Eves ND, Peterson BL, Garst J, Crawford J, West MJ, Mabe S, Harpole D, Kraus WE, Douglas PS. Safety and feasibility of aerobic training on cardiopulmonary function and quality of life in postsurgical nonsmall cell lung cancer patients: a pilot study. Cancer 2008; 113(12): 3430-9.

https://doi.org/10.1002/cncr.23967

[56] Wolff G, Davidson SJ, Wrobel JK, Toborek M. Exercise maintains blood-brain barrier integrity during early stages of brain metastasis formation. Biochem Bioph Res Co 2015; 463: 811817.

https://doi.org/10.1016/j.bbrc.2015.04.153

[57] Friedenreich CM. The role of physical activity in breast cancer etiology. Semin Oncol 2010; 37(3): 297-302.

https://doi.org/10.1053/j.seminoncol.2010.05.008

[58] Poier D, Büssing A, Recchia DR, et al. Influence of a multimodal and multimodal-aerobic therapy concept on health-related quality 
of life in breast cancer survivors. Integr Cancer Ther 2019; 18 : 1534735418820447.

https://doi.org/10.1177/1534735418820447

[59] Dieli-Conwright CM, Courneya KS, Demark-Wahnefried W, Sami N, Lee K, Sweeney FC, Stewart C, Buchanan TA, Spicer D, Tripathy D, Bernstein L, Mortimer JE. Aerobic and resistance exercise improves physical fitness, bone health, and quality of life in overweight and obese breast cancer survivors: a randomized controlled trial. Breast Cancer Res 2018; 20(1): 124.

https://doi.org/10.1186/s13058-018-1051-6

[60] Aoi W, Naito Y, Takagi T, et al. Regular exercise reduces colon tumorigenesis associated with suppression of iNOS. Biochem Bioph Res Co 2010; 399: 14-19.

https://doi.org/10.1016/j.bbrc.2010.07.023

[61] Chao A, Connell CJ, Jacobs EJ, McCullough ML, Patel AV, Calle EE, Cokkinides VE, Thun MJ. Amount, type, and timing of recreational physical activity in relation to colon and rectal cancer in older adults: the Cancer Prevention Study II Nutrition Cohort. Cancer Epidemiol Biomarkers Prev 2004; 13: 2187-2195.

[62] Mahmood S, English DR, Maclnnis RJ, Karahalios A, Owen N, Milne RL, Giles GG, Lynch BM. Domain-specific physical activity and the risk of colorectal cancer: results from the Melbourne Collaborative Cohort Study. BMC Cancer 2018; 18: 1063. https://doi.org/10.1186/s12885-018-4961-x

[63] Lynch BM, Cerin E, Owen N, Aitken JF. Associations of leisuretime physical activity with quality of life in a large, populationbased sample of colorectal cancer survivors. Cancer Causes Control 2007; 18(7): 735-42.

https://doi.org/10.1007/s10552-007-9016-6

[64] Thraen-Borowski KM, Gennuso KP, Cadmus-Bertram L. Accelerometer-derived physical activity and sedentary time by cancer type in the United States. PLoS One 2017; 12(8): e0182554. https://doi.org/10.1371/journal.pone.0182554

[65] Brown JC, Damjanov N, Courneya KS, Troxel AB, Zemel BS, Rickels MR, Ky B, Rhim AD, Rustgi AK, Schmitz KH. A randomized dose-response trial of aerobic exercise and healthrelated quality of life in colon cancer survivors. Psychooncology 2018; 27(4): 1221-1228.

https://doi.org/10.1002/pon.4655

[66] Meyerhardt JA, Giovannucci EL, Holmes MD, Chan AT, Chan JA, Colditz GA \& Fuchs CS (2006) Physical activity and survival after colorectal cancer diagnosis. J Clin Oncol 24: 3527-3534. https://doi.org/10.1200/JCO.2006.06.0855

[67] Grotta A, Bottai M, Adami HO, Adams SA, Akre O, Blair SN, et al. Physical activity and body mass index as predictors of prostate cancer risk. World Journal of Urology 2015; 33(10): 1495-502. https://doi.org/10.1007/s00345-014-1464-5

[68] Campos C, Sotomayor P, Jerez D, González J, Schmidt CB, Schmidt K, Banzer W, Godoy AS. Exercise and prostate cancer: From basic science to clinical applications. Prostate 2018; 78(9): 639-645.

https://doi.org/10.1002/pros.23502

[69] Vashistha V, Singh B, Kaur S, Prokop LJ, Kaushik D. The Effects of Exercise on Fatigue, Quality of Life, and Psychological Function for Men with Prostate Cancer: Systematic Review and Meta-analyses. Eur Urol Focus 2016; 2(3): 284-295. https://doi.org/10.1016/j.euf.2016.02.011

[70] Yunfeng G, Weiyang $H$, Xueyang $H$, Yilong $H$, Xin G. Exercise overcome adverse effects among prostate cancer patients receiving androgen deprivation therapy: An update metaanalysis. Medicine (Baltimore) 2017; 96(27): e7368. https://doi.org/10.1097/MD.0000000000007368

[71] Galvão DA, Taaffe DR, Spry N, et al. Exercise Preserves Physical Function in Prostate Cancer Patients with Bone Metastases. Med Sci Sports Exerc 2018; 50(3): 393-399. https://doi.org/10.1249/MSS.0000000000001454

[72] Friedenreich CM, Neilson HK, Farris MS, Courneya KS. Physical Activity and Cancer Outcomes: A Precision Medicine Approach. Clinical cancer research: an official journal of the American Association for Cancer Research 2016; 22(19): 4766-75. https://doi.org/10.1158/1078-0432.CCR-16-0067

[73] Psaltopoulou T, Ntanasis-Stathopoulos I, Tzanninis IG, Kantzanou M, Georgiadou D, Sergentanis TN. Physical Activity and Gastric Cancer Risk: A Systematic Review and MetaAnalysis. Clinical journal of sport medicine: official journal of the Canadian Academy of Sport Medicine 2016; 26(6): 445-64. https://doi.org/10.1097/JSM.0000000000000316

[74] Xie F, You Y, Huang J, et al. Association between physical activity and digestive-system cancer: An updated systematic review and meta-analysis. J Sport Health Sci 2021; 10(1): 4-13. https://doi.org/10.1016/.j.jshs.2020.09.009

[75] Phu S, Boersma D, Duque G. Exercise and Sarcopenia. J Clin Densitom 2015; 18(4): 488-92.

\section{https://doi.org/10.1016/j.jocd.2015.04.011}

[76] Yamamoto K, Nagatsuma Y, Fukuda Y, et al. Effectiveness of a preoperative exercise and nutritional support program for elderly sarcopenic patients with gastric cancer. Gastric Cancer 2017; 20(5): 913-918.

https://doi.org/10.1007/s10120-016-0683-4

[77] O'Neill L, Moran J, Guinan EM, Reynolds JV, Hussey J. Physical decline and its implications in the management of oesophageal and gastric cancer: a systematic review. J Cancer Surviv 2018; 12(4): 601-618. https://doi.org/10.1007/s11764-018-0696-6

[78] Lee J. Associations between Physical Activity and Liver Cancer Risks and Mortality: A Systematic Review and Meta-Analysis. Int J Environ Res Public Health 2020; 17(23): 8943. Published 2020. https://doi.org/10.3390/ijerph17238943

[79] Baumeister SE, Leitzmann MF, Linseisen J, Schlesinger S. Physical Activity and the Risk of Liver Cancer: A Systematic Review and Meta-Analysis of Prospective Studies and a Bias Analysis. J Natl Cancer Inst 2019; 111(11): 1142-1151.

https://doi.org/10.1093/jnci/djz111

[80] Ukawa S, Tamakoshi A, Wakai K, Kurozawa Y. Associations of daily walking and television viewing time with liver cancer mortality: findings from the Japan Collaborative Cohort Study. Cancer Causes Control 2014; 25(7): 787-93. https://doi.org/10.1007/s10552-014-0380-8

[81] Rezende LFM, Sa TH, Markozannes G, et al. Physical activity and cancer: an umbrella review of the literature including 22 major anatomical sites and 770000 cancer cases. $\mathrm{Br} \mathrm{J}$ Sports Med 2018; 5213: 826-833.

https://doi.org/10.1136/bjsports-2017-098391

[82] Bianchi A, Marchetti L, Hall Z, et al. Moderate Exercise Inhibits Age-Related Inflammation, Liver Steatosis, Senescence, and Tumorigenesis. J Immunol 2021; 206(4): 904-916. https://doi.org/10.4049/jimmunol.2001022

[83] Kaibori M, Ishizaki M, Matsui K, Nakatake R, Yoshiuchi S Kimura Y, Kwon AH. Perioperative exercise for chronic liver injury patients with hepatocellular carcinoma undergoing hepatectomy. Am J Surg 2013; 206(2): 202-9.

https://doi.org/10.1016/j.amjsurg.2012.07.035

[84] O'Neill L, Moran J, Guinan EM, Reynolds JV, Hussey J. Physical decline and its implications in the management of oesophageal and gastric cancer: a systematic review. J Cancer Surviv 2018; 12: $601-618$ https://doi.org/10.1007/s11764-018-0696-6

[85] Sinclair R, Navidi M, Griffin SM, Sumpter K. The impact of neoadjuvant chemotherapy on cardiopulmonary physical fitness in gastro-oesophageal adenocarcinoma. Ann R Coll Surg Engl 2016; 98(6): 396-400.

https://doi.org/10.1308/rcsann.2016.0135

[86] Whibley J, Peters CJ, Halliday LJ, Chaudry AM, Allum WH. Poor performance in incremental shuttle walk and cardiopulmonary exercise testing predicts poor overall survival for patients undergoing esophago-gastric resection. Eur J Surg Oncol 2018; 44(5): 594-599.

https://doi.org/10.1016/j.ejso.2018.01.242

[87] O'Neill LM, Guinan E, Doyle SL, Bennett AE, Murphy C, Elliott JA, et al. The RESTORE randomized controlled trial: impact of a multidisciplinary rehabilitative program on cardiorespiratory fitness in esophagogastric cancer survivorship. Ann Surg 2018; 268(5): 747-755 https://doi.org/10.1097/SLA.0000000000002895

[88] Shim YM. Impact of perioperative physical activity on postoperative pulmonary complications and quality of life among esophageal cancer patients. Clinicaltrialsgov Identifier: NCT03231462. Accessed 12 June 11, 2020. 
[89] O'Neill LM, Guinan E, Doyle SL, Bennett AE, Murphy C, Elliott JA, et al. The RESTORE randomized controlled trial: impact of a multidisciplinary rehabilitative program on cardiorespiratory fitness in esophagogastric cancer survivorship. Ann Surg 2018; 268(5): 747-755.

https://doi.org/10.1097/SLA.0000000000002895

[90] Fiore M, Cristaldi A, Okatyeva V, et al. Physical Activity and Thyroid Cancer Risk: A Case-Control Study in Catania (South Italy). Int J Environ Res Public Health 2019; 16(8): 1428. Published 2019. https://doi.org/10.3390/ijerph16081428

[91] Kim K, Gu MO, Jung JH, Hahm JR, Kim SK, Kim JH, Woo SH. Efficacy of a Home-Based Exercise Program After Thyroidectomy for Thyroid Cancer Patients. Thyroid 2018; 28(2): 236-245. https://doi.org/10.1089/thy.2017.0277

[92] Keimling M, Behrens G, Schmid D, Jochem C, Leitzmann MF. The association between physical activity and bladder cancer: systematic review and meta-analysis. $\mathrm{Br} \mathrm{J}$ Cancer 2014; 110: 1862-1870.

https://doi.org/10.1038/bjc. 2014.77

[93] Liss MA, White M, Natarajan L, Parsons JK. Exercise Decreases and Smoking Increases Bladder Cancer Mortality. Clin Genitourin Cancer 2017; 15(3): 391-395.

https://doi.org/10.1016/i.clgc.2016.11.006

[94] Behrens G, Leitzmann MF. The association between physical activity and renal cancer: systematic review and meta-analysis. Br J Cancer 2013; 108(4): 798-811. https://doi.org/10.1038/bjc.2013.37

[95] Liss M, Natarajan L, Hasan A, Noguchi JL, White M, Parsons JK. Physical Activity Decreases Kidney Cancer Mortality. Curr Urol 2017; 10(4): 193-198. https://doi.org/10.1159/000447180

[96] Tabaczynski A, Courneya KS, Trinh L. Replacing sedentary time with physical activity and sleep: associations with quality of life in kidney cancer survivors. Cancer Causes Control 2020; 31(7): 669-681.

https://doi.org/10.1007/s10552-020-01308-x

[97] Schouten LJ, Goldbohm RA, van den Brandt PA. Anthropometry, physical activity, and endometrial cancer risk: results from The
Netherlands Cohort Study. Int J Gynecol Cancer 2006; 16(suppl.2): 492.

https://doi.org/10.1111/j.1525-1438.2006.00676.x

[98] Dieli-Conwright $\mathrm{CM}, \mathrm{Ma} \mathrm{H}$, Lacey JV, et al. Long-term and baseline recreational physical activity and risk of endometrial cancer: the California Teachers Study. Br J Cancer 2013; 109: 761-8.

https://doi.org/10.1038/bjc.2013.61

[99] Millet N, McDermott HJ, Moss EL, Edwardson CL, Munir F. Increasing physical activity levels following treatment for cervical cancer: an intervention mapping approach [published online ahead of print, 2021 May 26]. J Cancer Surviv 2021; 1-9. https://doi.org/10.1007/s11764-021-01058-y

[100] Armstrong BK, Kricker A, English DR. Sun exposure and skin cancer. The Australasian Journal of Dermatology 1997; 38 Suppl 1: S1-6. https://doi.org/10.1111/i.1440-0960.1997.tb01000.x

[101] Greinert R, Boniol M. Skin cancer-primary and secondary prevention (information campaigns and screening)-with a focus on children \& sunbeds. Prog Biophys Mol Biol 2011; 107(3): 473476.

https://doi.org/10.1016/j.pbiomolbio.2011.08.008

[102] Michna L, Wagner GC, Lou Y-R, et al. Inhibitory effects of voluntary running wheel exercise on UVB-induced skin carcinogenesis in SKH-1 mice. Carcinogenesis 2006; 27(10): 2108-2115.

https://doi.org/10.1093/carcin/bgl057

[103] Walter RB, Buckley SA, White E. Regular recreational physical activity and risk of hematologic malignancies: results from the prospective VITamins And lifestyle (VITAL) study. Annals of oncology: official journal of the European Society for Medical Oncology / ESMO 2013; 24(5): 1370-7. https://doi.org/10.1093/annonc/mds631

[104] Hildebrand JS, Gapstur SM, Gaudet MM, Campbell PT, Pate AV. Moderate-to-vigorous physical activity and leisure-time sitting in relation to ovarian cancer risk in a large prospective US cohort. Cancer causes \& control: CCC 2015; 26(11): 1691-7. https://doi.org/10.1007/s10552-015-0656-7

https://doi.org/10.30683/1929-2279.2021.10.02

(C) 2021 Shashi K. Agarwal; Licensee Neoplasia Research.

This is an open access article licensed under the terms of the Creative Commons Attribution Non-Commercial License (http://creativecommons.org/licenses/by-nc/3.0/) which permits unrestricted, non-commercial use, distribution and reproduction in any medium, provided the work is properly cited. 